\title{
Forage Production of the Argentine Pampa Region Based on Land Use and Long-Term Normalized Difference Vegetation Index Data
}

\author{
Carlos M. Di Bella, ${ }^{1,2}$ Ignacio J. Negri, ${ }^{2}$ Gabriela Posse, ${ }^{3}$ Florencia R. Jaimes, ${ }^{4}$ Esteban G. Jobbágy, ${ }^{5}$ \\ Martin F. Garbulsky, ${ }^{6}$ and Victor A. Deregibus ${ }^{7}$
}

\begin{abstract}
Authors are ${ }^{1}$ Instituto Nacional de Tecnología Agropecuaria (INTA) and Consejo Nacional de Investigaciones Científicas y Tecnicas (CONICET) Researcher and Associate Professor, Instituto de Clima y Agua, Centro Nacional de Investigaciones Agropecuarias (CNIA)-INTA, Los Reseros y Las Cabañas S/N (CD 1686), Hurlingham, Buenos Aires, Argentina; ${ }^{2}$ Private Adviser, Departamento de Producción Animal, Cátedra de Forrajes, Facultad de Agronomía-Universidad de Buenos Aires, Av San Martín 4453 (CD C1417DSE), Ciudad Autónoma de Buenos Aires, Argentina; ${ }^{3}$ INTA Researcher, Instituto de Clima y Agua, CNIA-INTA, Los Reseros y Las Cabañas S/N (CD 1686), Hurlingham, Buenos Aires, Argentina; ${ }^{4}$ Doctoral Student, Instituto de Clima y Agua, CNIA-INTA, Los Reseros y Las Cabañas S/N (CD 1686), Hurlingham, Buenos Aires, Argentina; ${ }^{5}$ CONICET Researcher and Associate Professor, Grupo de Estudios Ambientales-Instituto de Matemática Aplicada San Luis, Universidad Nacional de San Luís. Ejercito de los Andes 950, ${ }^{\circ}$ piso (CP D5700) San Luis, Argentina; ${ }^{6}$ Doctoral Student and Associate Professor, Departamento de Producción Animal, Cátedra de Forrajes, Facultad de Agronomía-Universidad de Buenos Aires, Av San Martín 4453 (CD C1417DSE), Ciudad Autónoma de Buenos Aires, Argentina; and ${ }^{7}$ Titular Professor, Departamento de Producción Animal, Cátedra de Forrajes, Facultad de Agronomía-Universidad de Buenos Aires, Av San Martín 4453 (CD C1417DSE), Ciudad Autónoma de Buenos Aires, Argentina.
\end{abstract}

\begin{abstract}
Information about forage productivity and its interactions with cultural practices or climatic variation is necessary to plan livestock management and to increase production without damaging the environment. Remote sensing provides a valuable data source to achieve these goals. Here we characterize forage production over a large region ( 92 million hectares) by analyzing spatial, seasonal, and interannual variability with Normalized Difference Vegetation Index (NDVI) data. We identified 23 homogeneous zones that enclose multiple counties with similar characteristics of land use and productivity. A long-term series (1981-2000) of Advanced Very High Resolution Radiometer images were used to calculate monthly NDVI and the annual integral of NDVI (I-NDVI), which is an estimate of primary productivity, for each county. County agricultural land use data were used to resolve pure forage and crop NDVI patterns over time using a spectral unmixing model. The annual integral of NDVI was significantly associated with geographic longitude and average precipitation but not with latitude. Improved relationships between forage production and I-NDVI can be obtained by collecting more accurate forage estimates in the field and calculating radiation use efficiencies. Images of high temporal resolution allow the inference of seasonal changes, and images of high spatial resolution allow a more precise description of the forage resources.
\end{abstract}

\section{Resumen}

Disponer de información acerca de la productividad de forraje y de sus interacciones con las prácticas culturales o las variaciones climácticas es necesario para el diseño de un plan de manejo ganadero eficiente sin dañar el medio ambiente. En tal sentido, la teledetección puede proporcionar fuentes de datos alternativas. El objetivo de este trabajo fue caracterizar la producción de forraje a escala regional (92 millones de hectáreas), mediante el análisis espacial, estacional e interanual del índice verde de diferencia normalizada (NDVI). Se identificaron 23 zonas homogéneas que incluyeron un número variable de departamentos con características similares de uso de la tierra y la productividad. Se utilizaron imágenes del sensor Advanced Very High Resolution Radiometer del período 1981-2000 para calcular los valores mensuales y la integral anual del NDVI (INDVI), el cual es un estimador confiable de la productividad primaria a nivel de departamento. La información de usos del suelo para los distintos departamentos fue utilizada para estimar el NDVI de los recursos forrajeros y de los cultivos para cada zona homogénea utilizando un modelo espectral "subpixel". El integral anual del NDVI se asoció significativamente con la longitud y el promedio de precipitación pero no con la latitud. Es imprescindible para mejorar los productos provistos por la teledetección disponer de relaciones empíricas entre productividad y NDVI-I a partir de información de campo.

Key Words: linear spectral unmixing, NDVI, net primary production, NOAA-AVHRR, spatial variability, stocking rate

\section{INTRODUCTION}

Knowledge regarding forage productivity and its interactions with cultural practices and climatic variation on natural or

This work was financed by the Agencia Nacional de Promoción Científica y Tecnológica (ANPCyT, SECyT), throughout the PICT 2003, by INTA project no. 294000, 273220, and 294420 and by the Inter American Institute for Global Change Research (National Science Foundation GEO-0452325 through CRN 2031).

Correspondence: Carlos M. Di Bella. Email: cdibella@cnia.inta.gov.ar

Manuscript received 19 March 2008; manuscript accepted 16 November 2008. seminatural pastures has become fundamental both to plan livestock management and to increase secondary production. Three main aspects of annual precipitation can help characterize forage productivity: the annual average, the seasonal pattern, and the interannual variability (Paruelo et al. 1999). Annual average productivity determines the forage biomass available for livestock, seasonal pattern determines how this biomass is distributed throughout the year, and interannual variability defines production stability. The carrying capacity of forage resources is directly correlated with the annual 
average levels of their aboveground net primary productivity (ANPP) and inversely related to their temporal variability (McNaughton et al. 1991; Oesterheld et al. 1998; Paruelo et al. 1999).

In this context, farmers and policymakers require reliable, economic, and rapid methods to estimate forage productivity at a regional level. Productivity estimates through periodic harvests are expensive, time consuming, and often hard to scale up to whole paddocks or ranches. These direct measurements of ANPP are seriously constrained by labor and logistical difficulties (Singh et al. 1975; Lauenroth 1979). Since primary productivity is a function of photosynthetic active radiation intercepted by vegetation (Monteith 1977) and this variable can be estimated through information captured in different wavelengths, remote sensing can provide alternative data sources for estimating forage production over large areas. Nowadays, the use of remote sensing data is probably one of the best methodologies for regional productivity studies (Gamon et al. 1995; Posse and Cingolani 2000; Running et al. 2000; Posse et al. 2005). Satellite information, through empiric relationships between certain functional vegetation characteristics and some spectral indices, has become a relatively economic and available tool to estimate green biomass, leaf area index (Tucker et al. 1985; Wanjura and Hatfield 1987; Paruelo et al. 1997; Moulin et al. 1998), primary productivity (Tucker et al. 1985; Oesterheld et al. 1998; Gower et al. 1999; Paruelo et al. 2000), or evapotranspiration (Di Bella et al. 2000) at a regional scale as well as for land use classifications (De Fries et al. 1998; Cingolani et al. 2004) and for the definition of ecosystem functional types (Paruelo et al. 2001) among others. There are several indices that exploit the reflectance differences between the green vegetation and the rest of the land covers. Among them, Rouse et al. (1974) proposed the Normalized Difference Vegetation Index (NDVI), calculated as

$$
\mathrm{NDVI}=\frac{\mathrm{NIR}-\mathrm{R}}{\mathrm{NIR}+\mathrm{R}}
$$

where $R$ describes red band reflectance and NIR describes near infrared band reflectance of the electromagnetic spectrum. The NDVI integrated along time (generally one seasonal growth) presents a high correlation with the ANPP (Goward et al. 1985; Justice et al. 1985; Tucker et al. 1985; Burke et al. 1991; Paruelo and Lauenroth 1998), and this association is stronger than the existing one between the ANPP and precipitation (Oesterheld et al. 1998). The narrow relationship between ANPP and NDVI can be explained because NDVI is closely related to a fraction of the photosynthetic active radiation absorbed by the vegetation (fAPAR; Lo Seen et al. 1995; Rasmussen 1998; Gower et al. 1999; Reeves et al. 2001), and production depends directly on it. In systems like the one we studied, fAPAR corresponds almost exclusively with the green fAPAR since small quantities of nongreen vegetation accumulated because of the field management.

Satellites with a high revisited frequency such as the National Oceanic and Atmospheric Administration Advanced Very High Resolution Radiometer (NOAA-AVHRR) and spectral bands in the red and near infrared bands provide a useful tool to monitor vegetation. The resolution of these sensors $\left(1.1 \mathrm{~km}^{2}\right.$ at nadir) is appropriate for regional analysis. The National Aeronautics and Space Administration (NASA) has gathered and corrected a long-term time series of NOAA images from different NOAA platforms, from 1981 to 2000. This series, the Pathfinder AVHRR Land data set, offers the possibility of making a long-term analysis of forage production at $8 \times 8 \mathrm{~km}^{2}$ spatial resolution. The low resolution represents an undesirable characteristic since pixels (minimum area from which reflectance values were obtained) were greater than paddocks. So, the radiance values obtained from each pixel may come from areas having different land use and cover (Fischer 1994). Considering the difficulty of estimating forage productivity through NDVI in mixed landscapes (agricultural, pastures, and rangelands) and the use of low spatial resolution satellites, a method for subpixel classification has been developed (Fischer 1994; Kerdiles and Grondona 1995; Faivre and Fischer 1996; Moulin et al. 1998). This linear model evaluates the statistical decomposition of pixel information that allows estimation of signatures from pure resources from composite pixels $(8 \times$ $8 \mathrm{~km}^{2}$ ) knowing the proportion of each land use and cover over the mixed pixel.

Extensive agriculture and cattle production, including cowcalf operations and pasture finishing of steers, are dominant activities in the Pampas, playing a fundamental role in the economy of Argentina (Deybe and Flichman 1991) and in global food production (Imhoff et al. 2004). The region supports $\sim 38$ million cattle representing $76 \%$ of the national livestock (Agriculture, Livestock, Fishery and Food Secretary [AGPyA], 2000 report). This activity, mainly under extensive management, depends almost exclusively on natural or seminatural pastures and grasslands.

The aim of this work was to characterize forage production of the Pampa region using remote sensing information. We used low spatial resolution satellite data because of the availability of long-term data sets of high temporal resolution. Vast extension of homogeneous environments makes this type of satellite data appropriate for the Pampas in Argentina. We extracted the NDVI of the forage resources of low-resolution images knowing the relative proportions of cultivated fields and native pastures and grasslands using a modified subpixel model (Kerdiles and Grondona 1995). We characterized the productivity of forage resources of the different areas in the Pampa region by analyzing the NDVI variations in relation to spatial, seasonal, and annual variability.

\section{MATERIALS AND METHODS}

\section{Study Area}

The study area covers 92 million ha, including six provinces of Argentina: Buenos Aires, Santa Fé, Córdoba, Entre Ríos, Corrientes, and La Pampa (Fig. 1). Each province is divided into several counties (i.e., smallest administrative unit). Mean annual temperature ranges between $10^{\circ}$ and $20^{\circ} \mathrm{C}$ and annual rainfall between $400 \mathrm{~mm}$ and $1600 \mathrm{~mm}$, decreasing from the northeast to the southwest. Soils are mainly Mollisols (Soriano 1991), but the region includes significant areas of Alfisols, Inceptisols, and, in the northeastern area, Ultisols and Oxisols. 


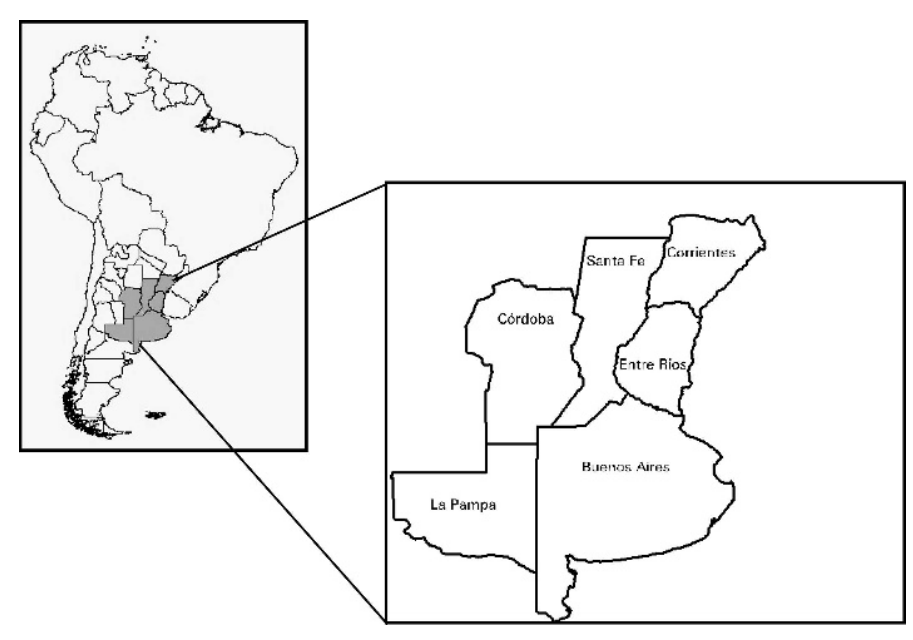

Figure 1. Pampa region in Argentina (South America).

\section{Zoning of the Pampas}

Because of the great size of the area, we created several forage production zones using a decision tree (Belward and de Hoyos 1987; Freidl and Brodley 1997) based on several climatic and productive variables. These zones enabled us to describe the forage functional dynamics across the entire area. The variables considered were forage productivity, information on productive activities at the county scale, and land use/cover obtained from the Agricultural National Census (Instituto Nacional de Estadísticas y Censos 1988). We also used monthly mean temperature as a meteorological variable. As an estimation of grazing pressure, we developed the Cattle Index (C.I.). To allocate the number of head of livestock reported in each individual county to its corresponding pasture/grassland area, we excluded agricultural land and unproductive zones, such as lakes or cities. The following equation was used:

$$
\text { C.I. }=\frac{h d}{\sum_{i=1}^{4} a_{i}}
$$

where $h d=$ number of livestock of the county, $a_{i}=$ surface of pasture fields or "grazing land" corresponding to the county, $a_{1}=$ area with perennial forage, $a_{2}=$ area with annual forage, $a_{3}=$ area of natural grassland, and $a_{4}=$ shrubland area (we assumed that these areas had an understory of grasses). This index is also a useful a priori estimation of primary productivity since the stocking rate is adjusted to forage availability. To characterize different types of forage production across counties, we considered percentage of forage cultivated area, relative forage species in the cultivated area, percentage of area with natural grassland, percentage of shrubland area, and the main cattle activity. Monthly temperature data were obtained from the National Institute of Agricultural Technology of Argentina (Instituto Nacional de Tecnología Agropecuaria [INTA] in Spanish), which has meteorological databases in the study area. All these data were used at the county level. The values for determination criteria of the decision tree were taken arbitrarily and then changed iteratively, looking for the contiguity of the county belonging to the same zone. Area delineation was adjusted to the boundaries of the county. Finally, the threshold values for the decision tree were mean annual temperature lower or higher than $18^{\circ} \mathrm{C}$, different values of C.I. $(0.25,0.47,0.66,0.95,1.04$, and 1.13$)$, and percentages of agriculture, natural grassland, or shrubland area and geographical continuity.

\section{NDVI Characterization}

We worked with a long-term series (1981-2000) of AVHRR images with $8 \times 8 \mathrm{~km}^{2}$ spatial resolution from the Pathfinder AVHRR Land data set (James and Kallury 1994). This data set, which was originated from NOAA-7, -9, -11, and -14 satellite images, was radiometrically and geometrically corrected (Rao and Chen 1995). To minimize cloud and atmospheric interference, and other degrading effects, we produced monthly maximum NDVI composite images from the original 10-d data (Holben 1986). Data from May 1994 to June 1995 were not available because of satellite reception problems. Finally, the analysis was carried out with 199 monthly images (from July 1981 to March 2000).

Over each image, monthly pixel values were extracted and averaged for each county. Then we calculated the monthly NDVI over the defined homogeneous areas. To do this, we calculated the weighted averages of the relative area of each county to the total area. $\mathrm{NDVI}_{\text {zonal }}$ was calculated as the spatially weighted average of the county values:

$$
\mathrm{NDVI}_{\text {zonal }}=\sum_{i=1}^{n} i v_{i} \cdot \frac{s_{i}}{S}
$$

where $i v_{i}=$ NDVI average of the county $i$ of the area, $s_{i}=$ surface of the county $i, S=$ total surface of the homogeneous area, and 1 to $n=$ counties of the area.

Others parameters were calculated to characterize NDVI data variability: the annual integral of the $\mathrm{NDVI}_{\text {zonal }}$ (JulyJune) and the average and the coefficient of variation of each zone for the 1981-1982 and 1998-1999 periods (only the years with all monthly images without contamination). The annual integral of the NDVI (I-NDVI) was calculated according to the procedure described by Paruelo et al. (1997), in which the NDVI product and the proportion of the year covered by each compound were added (in our case 1/12 since we used monthly intervals).

\section{Characterization of the Forage Resources: NDVI Pure Signature}

The NDVI values obtained for each county correspond not only to the reflectance signature of pastures and natural grasslands but also to the integrated signals of pastures, cultivations, water bodies, and other land uses because of the large pixel size used for this analysis. To understand pasture dynamics, it was necessary to discriminate the different pixel component signals and their contributions to obtain an indicator of pasture productivity in those areas of mixed land uses and surface features. A statistical technique was used to separate the contribution of each vegetation class into a pixel and obtain the pure signature of forage dynamics, starting from complex pixels (e.g., Kerdiles and Grondona 1995; Di Bella et al. 2004). 

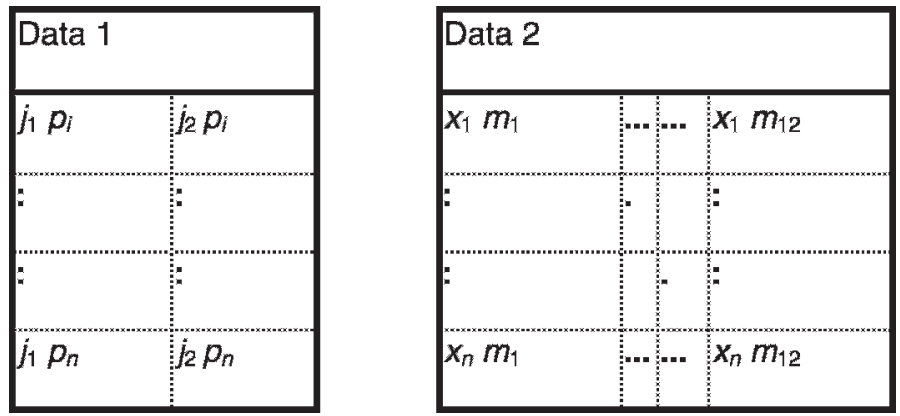

Figure 2. Schematic information used to obtain the forage Normalized Difference Vegetation Index (NDVI) of each zone. $p_{i}=$ county $i$ of zone A; $j_{1} p_{i}=$ grassland and pasture proportion in the county $i$ in year $\mathrm{B} ; j_{2} p_{i}=$ crop proportion in the county $i$ in year $\mathrm{B} ; x_{1-n} m_{i}=$ NDVI of the county $1-n$ in month $m_{i}: m_{1} \ldots m_{12}=$ months: $1=$ July, $12=$ June.

The subpixel technique, or linear mixture model, considers that the pixel radiance results from the linear combination of the radiances of the elements that compose it, multiplied by their respective proportion in the pixel. Constituent elements were named "end members." The signal of the pixel $x$ in the band $i$ $\left(x_{i}\right)$ is defined as

$$
x_{i}=\sum_{j=1}^{n} f_{j} m_{i j}+e_{i}
$$

where $f_{j}$ is the proportion of the component $j$ in the pixel, $m_{i j}$ is the spectral response of the component $j$ in the band $i$ (which was the unknown value), and $e_{i}$ is the error term. The model assumes constant response of end member $j$ over the zone (Kerdiles and Grondona 1995).

We used the model of Faivre and Fischer (1996), where the analysis unit (pixel) was the county, which is the minimum unit for which we had information (from the series of estimations of cultivated surface of the Agriculture, Fishing and Food Secretary [SAGPyA in Spanish]). $x_{i}$ is the $\mathrm{NDVI}_{\text {county }}$, the value that we extracted from the images; $f_{j 1} f_{j n}$ are the fractions of each land use in county; and $m_{i j}$ is the signal of the components, for example, pastures and grasslands, which are the unknown values. The components taken into account were $j_{1}=$ pastures and grasslands and $j_{2}=$ cropland. This procedure was carried out independently for each homogeneous zone defined previously. The schematic information used to obtain the forage NDVI of each zone is presented in Figure 2.

Thus, in the general model shown as Equation 4, $x_{i}$ was obtained from the $\mathrm{NDVI}_{\text {county }} ; j_{1} j_{n}$ are the proportions of each land use of the county; $m_{i j}$ is the signal of the pure components, for example, pastures and natural grasslands that we wanted to discriminate; and $p_{i}$ is the county $i$. We assumed that the spectral response of the individualized components is constant within the counties that compose each defined zone. Each zone is formed by several counties. We worked directly with the NDVI values and not with the red and infrared band values because this index has a special significance and allows the characterization of forage dynamics, thus summarizing the spectral data. All the actions made over materials and methods were summarized on a flux diagram, shown in Figure 3.

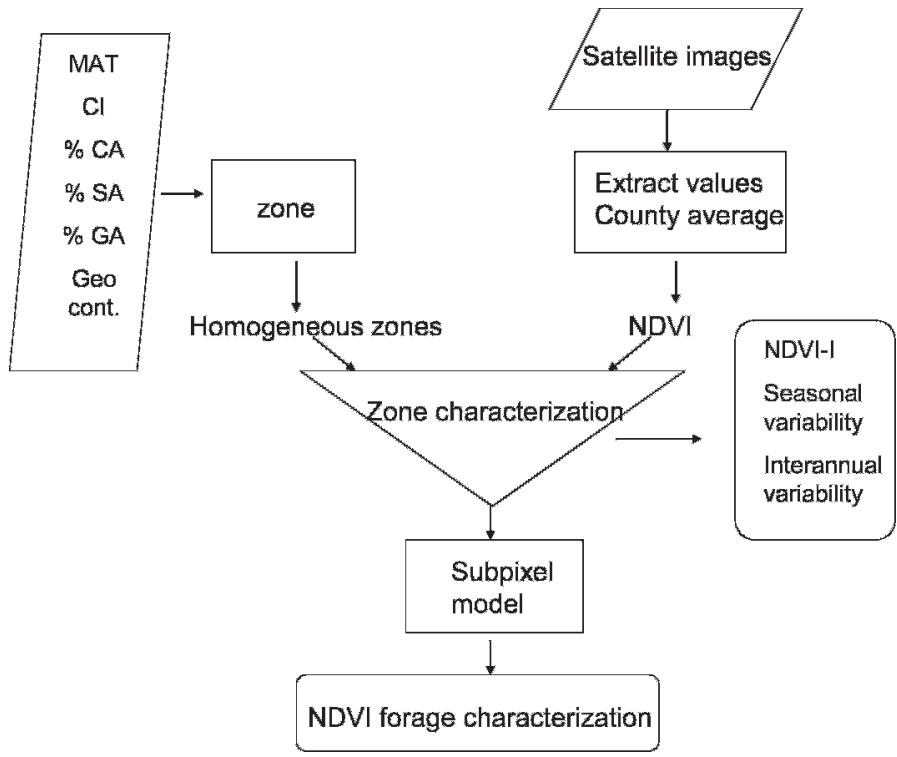

Figure 3. Flux diagram with the general methodology followed by us to obtain zone and Normalized Difference Vegetation Index (NDVI) forage characterization.

\section{RESULTS AND DISCUSSION}

We identified 23 homogeneous areas or "zones" that included counties with similar characteristics of land use and productivity (Fig. 4). Among them, there were different characteristics according to the cattle index (number of cattle/forage resources) and proportion of cultivated land and natural vegetation. Although within each homogeneous zone there was not a pure land use/cover, since each contained areas with different kinds of use or cover (crops, grasslands, cities, and small water bodies), the $\mathrm{NDVI}_{\text {zonal }}$ summarized the general behavior of vegetation in each zone along the year, averaging data from 1981 to 1999 (Fig. 5). As in other locations and in spite of the low spatial resolution, these values were very useful to quickly characterize the vegetation dynamics and phenology (Tucker 1980; Taylor et al. 1985; Reed et al. 1994; Posse and
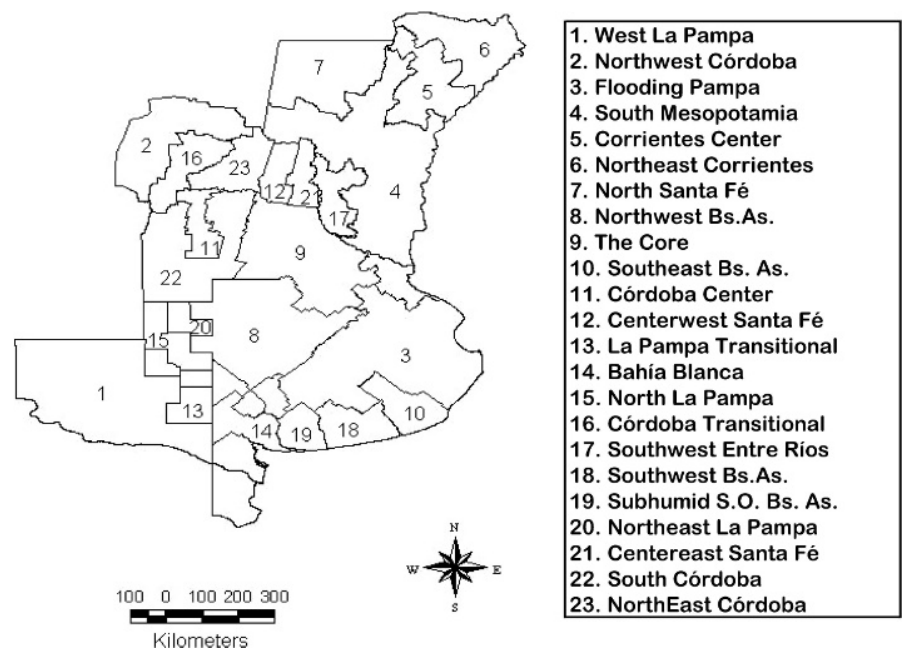

Figure 4. Pampa region zoning based on Instituto Nacional de Estadísticas y Censos (1988) and ancillary information. 


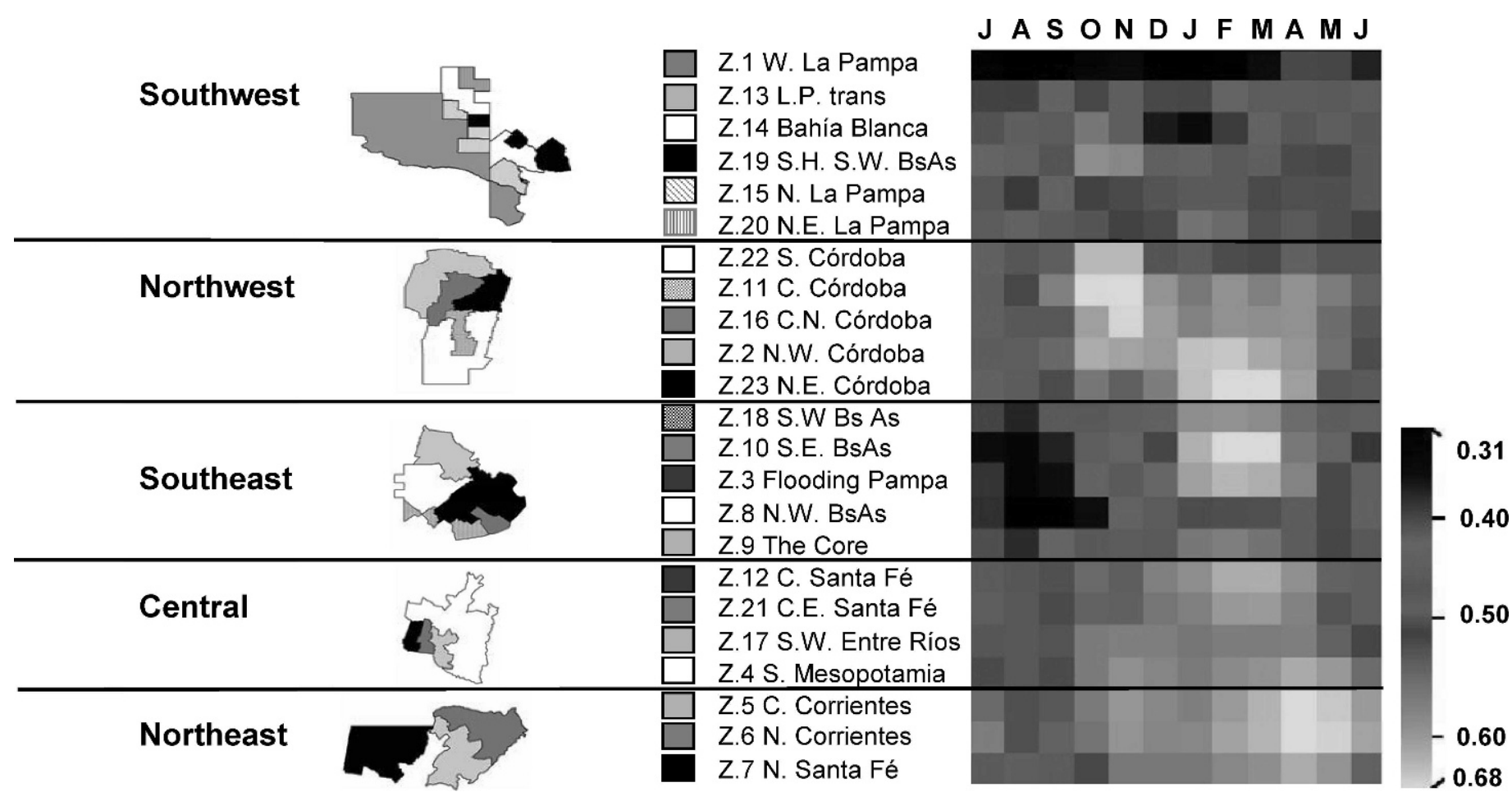

Figure 5. Annual evolution of Normalized Difference Vegetation Index (NDVI) per zone. The different gray levels represent NDVI monthly values, from July to June. Columns are months, and the zones are represented in the rows. Row references are codified on the left side of the maps. The scale is not lineal because the software used took into account the data histogram to perform it.

Cingolani 2000; Posse et al. 2005). Taking into account the geographical localization of each zone within the total area, the integrated values of NDVI (I-NDVI) were significantly associated with the longitude but not with latitude at the center of each zone (Figs. 6a and 6b). This positive relationship is likely driven by the underlying precipitation gradient (Fig 7). Mean annual precipitation explained $73 \%$ of the I-NDVI variance (I-NDVI $=0.1679 \ln$ [precipitation] $-0.6205, R^{2}=$ 0.737 ), suggesting that primary productivity is restricted by water availability. A similar relationship has been previously found for Template South America (Paruelo et al. 2001). Rasmussen (1998) found a very strong linear relationship between both variables for Senegal $\left(R^{2}=0.81\right.$ and $R^{2}=0.95$ for the years 1990 and 1991, respectively), and Jobbágy et al. (2002) found a linear relationship for two precipitation gradients in Patagonia (Argentina). The small range of precipitation of both studies, up to $500 \mathrm{~mm}$, explains the linear relationship between these variables.

We also found a significant negative correlation between the annual integral average NDVI and its coefficient of variation $\left(\mathrm{CV}_{\mathrm{NDVI}}=-29.2 \cdot \mathrm{I}-\mathrm{NDVI}+23.7 ; R^{2}=0.78 ; P<0.01\right)$. Zones with lowest NDVI values showed a higher variability, associated with a continental position (areas 1, 13, 14, and 18). These areas were the most vulnerable since the low ANPP values and therefore the low secondary productivity values are accompanied by great uncertainty. On the other hand, zones
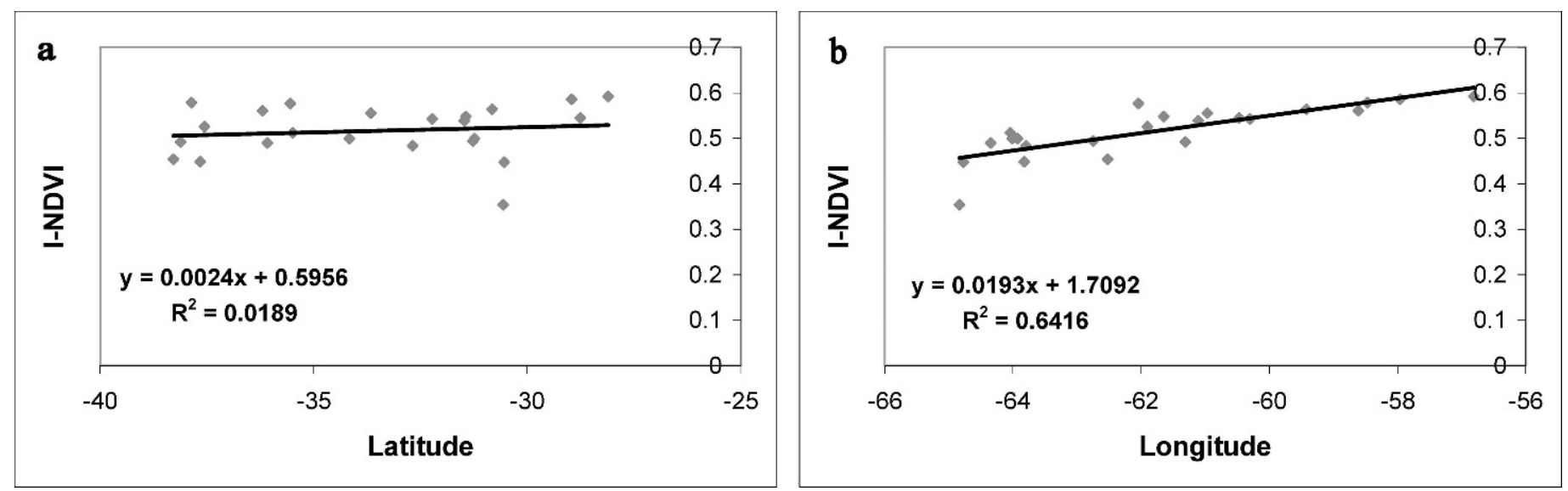

Figure 6. Relationship between annual integral Normalized Difference Vegetation Index (I-NDVI) and the central coordinate of each zone. a, Latitude: $y=0.0024 x+0.5956\left(R^{2}=0.0189\right)$. b, Longitude: $y=0.0193 x+1.7092\left(R^{2}=0.6416\right)$. 


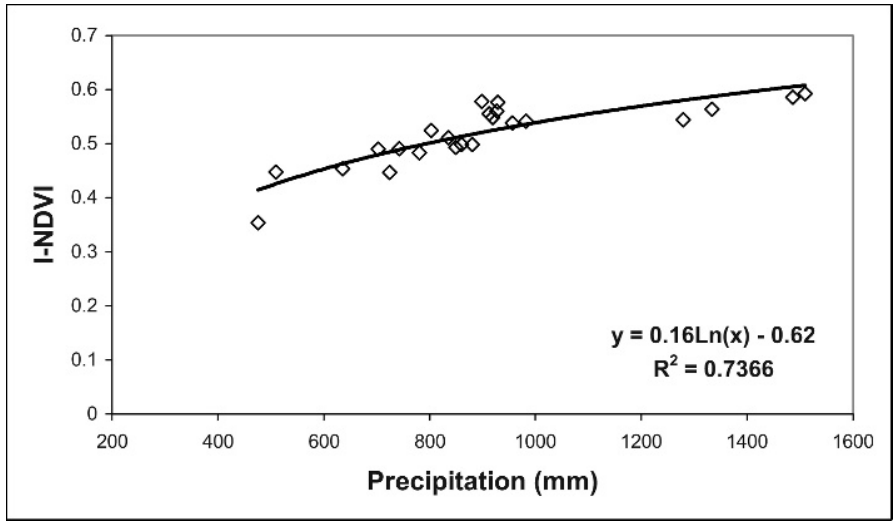

Figure 7. Relationship between average annual rainfall $(\mathrm{mm})$ from meteorological stations and integral Normalized Difference Vegetation Index (I-NDVI) for the 23 zones $\left(y=0.16 \ln [x]-0.62, R^{2}=0.73\right)$.

with higher values also presented more stability on their values (Fig. 8). A similar pattern was found by other authors in other regions (Oesterheld et al. 1998; Paruelo et al. 1999; Jobbágy et al. 2002), showing that as ANPP increases, its interannual variability diminishes exponentially.

When we evaluated the relationship between I-NDVI averaged by year and C.I., a positive relationship was found (Fig. 9). Because of NDVI saturation values, the relation was exponential. However, if we excluded five points from the lowest values, belonging to zone 1 (the driest one), the relation remained exponential with a lower regression coefficient (data not shown). Sala (2001) and Oesterheld et al. (1992) also reported exponential relationships between herbivore biomass and ANPP. The association between I-NDVI and C.I. was stronger when natural grassland areas from the east of the Pampa region-areas 3, 4, 5, and 6-were removed from the analysis (exponential adjustment in Fig. 9b). In these zones, we found an opposite trend, with INDVI increasing from south to north and C.I. diminished over the same gradient. Different environmental constraints of these zones may have modified floristic composition, causing declining proportions of biomass harvest by livestock.

The application of the subpixel model allowed us to compare forage and crop NDVI signatures within various zones through-

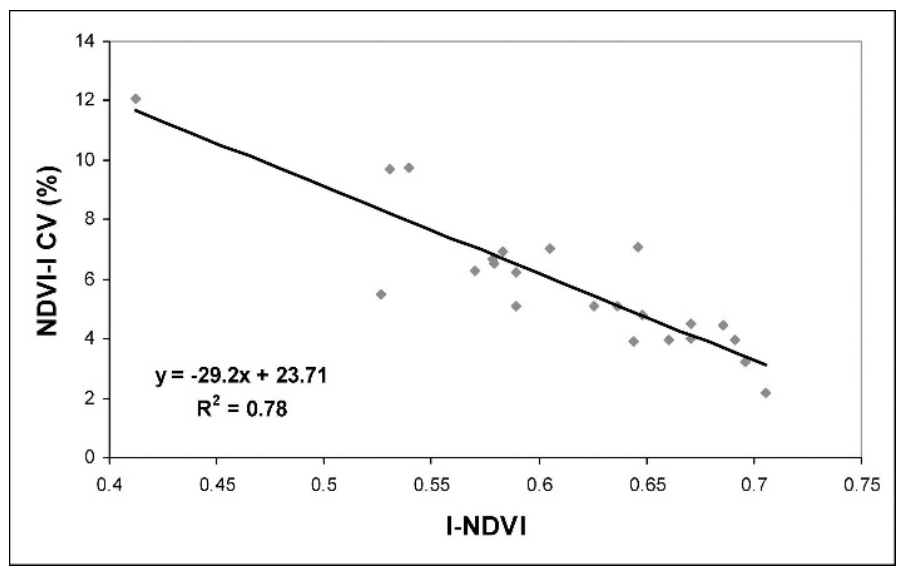

Figure 8. Relationship between integral Normalized Difference Vegetation Index (I-NDVI) and variation coefficient of I-NDVI for the 23 zones ( $y$ $=23.71-29.2 \cdot$ I-NDVI, $\left.R^{2}=0.78\right)$.
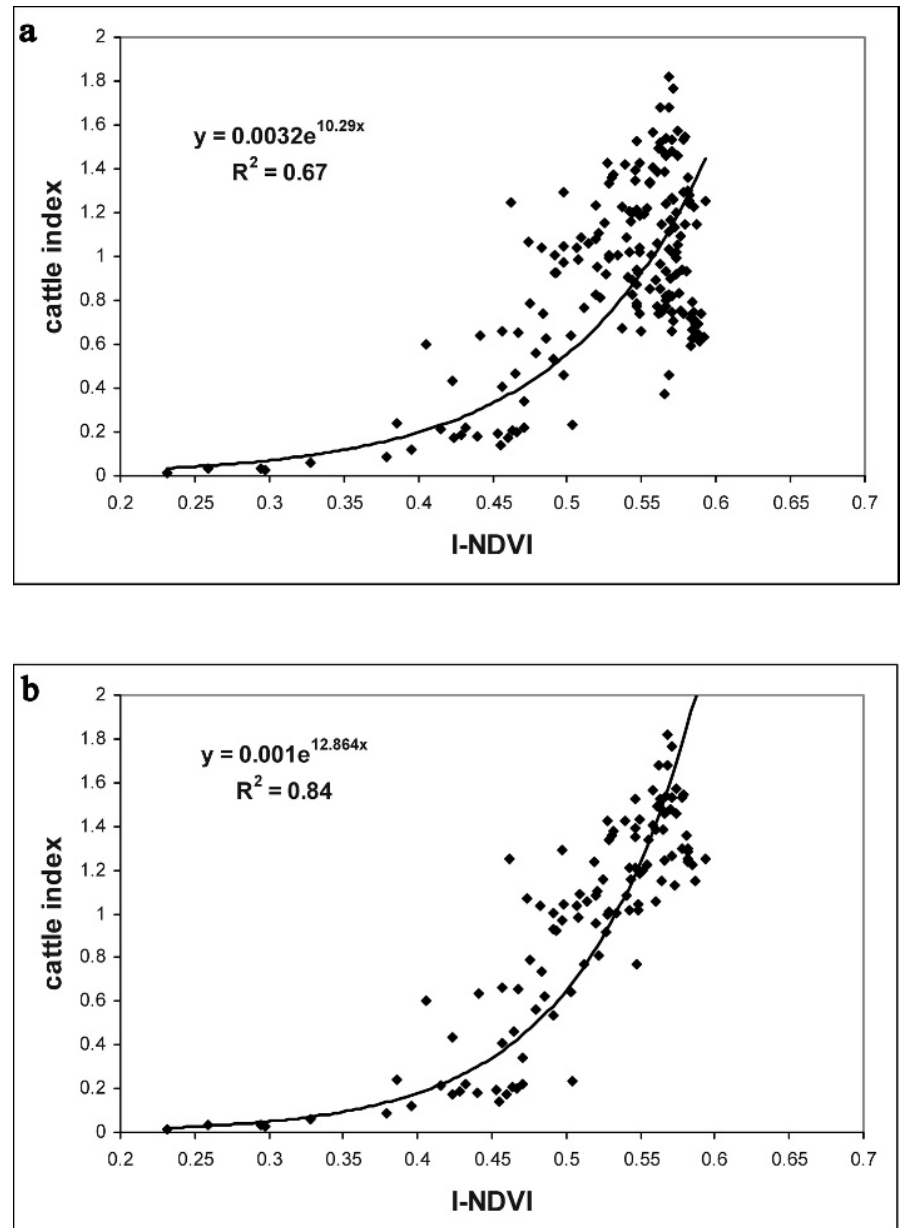

Figure 9. Relationship between cattle index and average integral Normalized Difference Vegetation Index (I-NDVI). a, The relationship for all counties $\left(y=0.0032 \mathrm{e}^{10.29 x}, R^{2}=0.67\right)$. b. The relationship for all counties except zones 3,4 , and $5\left(y=0.001 e^{12.864 x}, R^{2}=0.84\right)$.

out the year (Fig. 10). In the Flooding Pampas (Fig. 10a), the $\mathrm{NDVI}_{\text {forage }}$ was very similar to the $\mathrm{NDVI}_{\text {zonal }}$ since its vegetation was composed mostly of forage resources ( $\sim 90 \%$ every year). Forage resources in this area are composed mainly of natural grasslands. $\mathrm{NDVI}_{\text {forage }}$ was slightly higher than $\mathrm{NDVI}_{\text {zonal }}$ in December and January and smaller in February and March, when the summer crops presented higher NDVI values. Peak NDVI occurred in the spring simultaneously with peak productivity (Sala et al. 1981). A different land use and seasonality pattern occurred in the south Córdoba region (Fig. 10b). Cropland contribution to the $\mathrm{NDVI}_{\mathrm{zonal}}$ values was more important in the summer. In addition, the curve of $\mathrm{NDVI}_{\text {forage }}$ did not follow the same dynamics as that of $\mathrm{NDVI}_{\mathrm{zonal}}$. This implies that the use of this index may be inappropriate to study the productivity of forage resources over this area with the spatial resolution provided by NOAA-AVHRR satellite images. The $\mathrm{NDVI}_{\text {forage }}$ presented a bimodal profile with a summer decrease that did not appear in the $\mathrm{NDVI}_{\mathrm{zona}}$. In this area, the summer crops occupied approximately $30 \%$ of the surface (average from 1981 to 1999), whereas the winter crops occupied approximately $10 \%$ of the area. In the northeast of Córdoba and center of Santa Fe, dairy zones (Fig. 10c), the $\mathrm{NDVI}_{\text {forage }}$ showed an annual behavior similar to that in the South zone of Córdoba, although in this case 

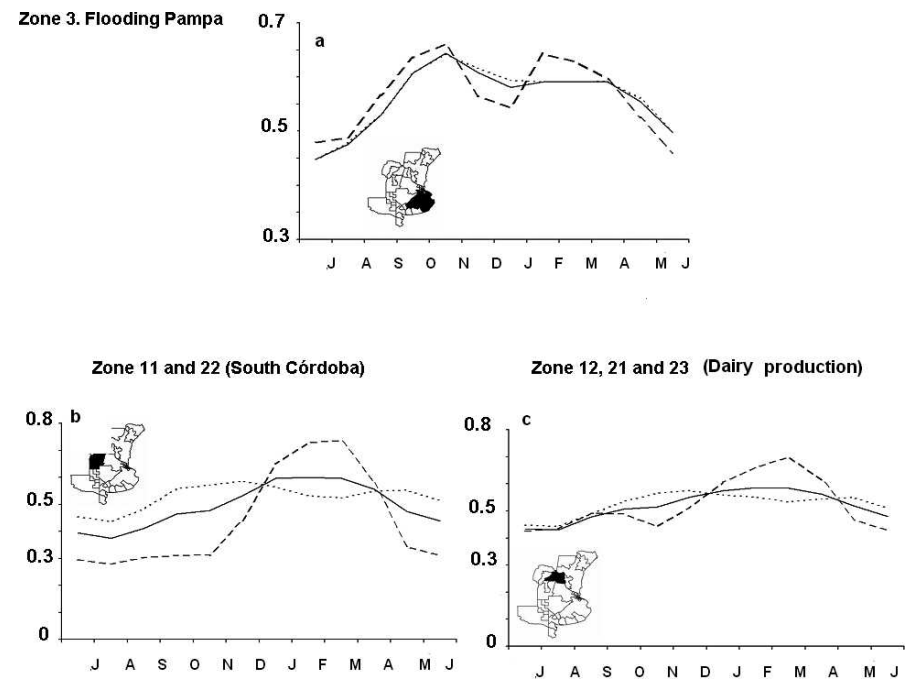

Figure 10. Average Normalized Difference Vegetation Index (NDVI) monthly values (for the 1981-1999 period, July-June) of NDVI $I_{\text {forage }}$ (dotted line), NDVI croplands (dashed line), and NDVI use NDVI values were obtained indirectly through the $\mathrm{NDVI}_{\text {zone }}$ values and information of relative crops and grasslands surfaces. a, Flooding pampa. b, South Córdoba. c, Dairy production zone (northwest of Córdoba-Center Santa Fe).

the summer decrease was less defined. The $\mathrm{NDVI}_{\text {forage }}$ peak took place before the $\mathrm{NDVI}_{\text {zonal, }}$, which occurred in summer principally by the effect of the summer crops. On the other hand, the winter crops (15\% of the surface in average) also affected the $\mathrm{NDVI}_{\text {zone }}$ curve, a fact that contributed to the peak observed in

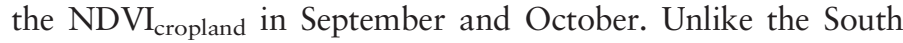
zone of Córdoba, integral values of $\mathrm{NDVI}_{\text {forage }}, \mathrm{NDVI}_{\text {zone }}$, and $\mathrm{NDVI}_{\text {cropland }}$ did not differ significantly. When we applied the subpixel model in order to obtain the $\mathrm{NDVI}_{\text {forage }}$ starting from the $\mathrm{NDVI}_{\mathrm{zonal}}$, diverse difficulties arose because the forage resources proportions had been estimated indirectly through the agricultural census. This added sources of uncertainty because of the imprecision of the agricultural estimates (L. Frank, personal communication, 2002) and because the overlapping of some cultivation areas of the Pampa region (e.g., a case of wheatsoybean cultivation) produced an estimation of the cultivated area greater than the real one.

Despite the importance of natural forage resources on livestock production in Argentina, there are not many studies describing unique zones of production or analyzing the seasonal and interannual vegetation characterization at a regional scale. By using the type of information described in this article, it is possible to develop monitoring programs to forecast forage productivity at regional levels. This will allow the prediction of livestock production and the demand for supplemental feeds like silage. The ability to forecast both forage and livestock production may provide a stabilizing factor for livestock prices since it will be possible to anticipate changes in livestock production patterns.

\section{IMPLICATIONS}

Our study shows the value of stratification in regional analysis when important climatic and land use contrasts exist. Taking into account the homogeneous zone definition, satellite images represent a very useful tool if good ground-truth data are available. If not, interpretation becomes very difficult and uncertain. The application of a subpixel model allowed us to use AVHRR images to estimate the productivity of individual forage resources processing heterogeneous $8 \mathrm{~km} \times 8 \mathrm{~km}$ pixels. We believe that it is imperative to improve the estimates of ANPP based on the I-NDVI and to identify two different approaches: 1) establishment of local empirical relationships between both variables or 2) estimates of energy to biomass conversion coefficients (radiation use efficiency) based on field data. For the last option, the semiempirical model by Monteith, in which NDVI can play as an estimate of $f$ APAR, is a valuable alternative. For studies with more spatial detail, Paruelo et al. (2000) have proposed the combined use of images with low spatial resolution and high temporal resolution with images of high space resolution and low temporal resolution (e.g., they propose, at paddock level, the use of NOAA AVHRR and Landsat Thematic Mapper). In this way, the images of high temporary resolution allow the inference of seasonal changes, and the images of high spatial resolution allow the correction between points, thus providing a more precise description of forage resources.

\section{ACKNOWLEDGMENTS}

We would like to thank L. Frank for his comments that helped improve this manuscript. We are grateful to the Associate Editor and anonymous reviewers who helped us improve the manuscript.

\section{LITERATURE CITED}

Belward, A. S., and A. de Hoyos. 1987. A comparison of supervised maximum likelihood and decision tree classification for crop cover estimation from multitemporal LANDSAT MSS data. International Journal of Remote Sensing 8:229-235.

Burke, I. C., T. G. F. Kittel, W. K. Lauenroth, P. Snook, C. M. Yonker, and W. J. Parton. 1991. Regional analysis of the central Great Plains. BioScience 41:685-692.

Cingolani, A. M., D. Reninson, M. R. Zak, and M. R. Cabido. 2004. Mapping vegetation in a heterogeneous mountain rangeland using Landsat data: an alternative method to define and classify land-cover units. Remote Sensing of Environment 92:84-97.

De Fries, R. S., M. Hansen, J. R. G. Townshend, and R. Sohlberg. 1998. Global land cover classification at $8 \mathrm{~km}$ spatial resolution: the use of training data derived form Landsat imagery in decision tree classifiers. International Journal of Remote Sensing 19:3141-3168.

DeYbe, D., And G. Flichman. 1991. A regional agricultural model using a plant growth simulation program as activities generator: an application to a region in Argentina. Agricultural Systems 37:369-385.

Di Bella, C. M., R. Faivre, F. Ruget, B. Seguin, M. Guérif, B. Combal, M. Weiss, and C. ReBelLA. 2004. Remote sensing capabilities to estimate pasture production in France. International Journal of Remote Sensing 25:5359-5372.

Di Bella, C. M., C. M. Rebella, and J. M. Paruelo. 2000. Evaporation estimates using NOAA AVHRR imagery in the Pampa region of Argentina. International Journal of Remote Sensing 21:791-797.

Faivre, R., AND A. FISCHER. 1996. Predicting crop reflectances using satellite data observing mixed pixels. Journal of Agricultural, Biological and Environmental Statistics 2:87-107.

FISCHER, A. 1994. A model for the seasonal variations of vegetation indices in coarse resolution data and its inversion to extract crop parameters. Remote Sensing of Environment 48:220-230. 
Freidl, M. A., and C. E. Brodley. 1997. Decision tree classification of land cover from remotely sensed data. Remote Sensing of Environment 61:399-409.

Gamon, J. A., C. B. Field, M. L. Goulden, K. L. Griffin, A. E. Hartley, G. Joel, J. Peñuelas, and R. Valentinl. 1995. Relationships between NDVI, canopy structure and photosynthesis in three Californian vegetation types. Ecological Applications 5:28-41.

Goward, S. N., C. J. Tucker, And D. G. Dye. 1985. North American vegetation patterns observed with NOAA-7 advanced very high resolution radiometer. Vegetatio 64:3-14.

Gower, S. T., C. J. Kucharik, and M. Norman. 1999. Direct and indirect estimation of leaf area index, fAPAR, and net primary production of terrestrial ecosystems. Remote Sensing of Environment 70:29-51.

Holben, B. N. 1986. Characteristics of maximum-value composite images from temporal AVHRR data. International Journal of Remote Sensing 7:1417-1434.

Imhoff, M. L., L. Bounoua, T. Ricketts, C. Loucks, R. Harriss, and W. T. Lawrence. 2004. Global patterns in human consumption of net primary production. Nature 429:870-873.

Instituto Nacional de Estadísticas y Censos. 1988. Censo Nacional Agropecuario, Informes finales por provincias. Presidencia de la Nación. Secretaría de Planificación. Buenos Aires, Argentina: Instituto Nacional de Estadísticas y Censos.

James, M., And S. Kallury. 1994. The pathfinder AVHRR land data set: an improved coarse resolution data set for terrestrial monitoring. International Journal of Remote Sensing 15:3347-3364.

Jobbágy, E. G., 0. E. Sala, and J. M. Paruelo. 2002. Patterns and controls of primary production in the Patagonian steppe: a remote sensing approach. Ecology 83:307-319.

Justice, C. O., J. R. G. Townshend, B. N. Holben, and C. J. Tucker. 1985. Analysis of the phenology of global vegetation using meteorological satellite data. International Journal of Remote Sensing 6:1271-1318.

Kerdiles, H., and M. O. Grondona. 1995. NOAA-AVHRR NDVI decomposition and subpixel classification using linear mixing in the Argentinean Pampa. International Journal of Remote Sensing 16:1303-1325.

LAUENROTH, W. K. 1979. Grassland primary production: North American grasslands in perspectives. In: N. R. French [ED.]. Perspectives in grasslands ecology. Ecological studies, Volume 32. New York, NY, USA: Springer-Verlag. p. 3-22.

Lo Seen, D., E. Mougin, S. Rambal, A. Gaston, and P. Hiernaux. 1995. A regional sahelian grassland model to be coupled with multispectral satellite data. II: toward the control of its simulations by remotely sensed indices. Remote Sensing of Environment 52:194-206.

McNaughton, S. J., M. Oesterheld, D. A. Frank, and K. J. Williams. 1991. Primary and secondary production in terrestrial ecosystems. In: J. Cole, G. Lovett, and S. Findlay [EDS.]. Comparative analyses of ecosystems: patterns, mechanisms and theories. New York, NY, USA: Springer-Verlag. p. 120-139.

Monteith, J. L. 1977. Climate and efficiency of crop production in Britain. Philosophical Transactions of the Royal Society of London, Series B 281:277-294.

Moulin, S., A. Bondeau, and R. Delécolle. 1998. Combining agricultural crop models and satellite observations: from field to regional scales. International Journal of Remote Sensing 19:1021-1036.

Oesterheld, M., C. M. Di Bella, and H. Kerdiles. 1998. Relation between NOAAAVHRR satellite data and stocking rate of rangelands. Ecological Applications 8:207-212.

Oesterheld, M., O. E. Sala, and S. J. McNaughton. 1992. Effect of animal husbandry on herbivore-carrying capacity at a regional scale. Nature 356:234-236.

Paruelo, J. M., H. E. Epstein, W. K. Lauenroth, and I. C. Burke. 1997. AnPP estimates from NDVI for the central grassland region of the United States. Ecology 78:953-958.

Paruelo, J. M., M. F. Garbulsky, J. P. Guerschman, and M. Oesterheld. 1999. Caracterización regional de los recursos forrajeros de las zonas templadas de la Argentina mediante imágenes satelitales. Revista Argentina de Producción Animal 19:125-131.

Paruelo, J. M., E. G. Jobbagy, and 0. E. Sala. 2001. Current distribution of ecosystem functional types in temperate South America. Ecosystems 4:683-698.

Paruelo, J. M., and W. K. Lauenroth. 1998. Interannual variability of NDVI and its relationship to climate for North American shrublands and grasslands. Journal of Biogeography 25:721-733.

Paruelo, J. M., M. Oesterheld, C. M. Di Bella, M. Arzadum, J. Lafontaine, M. Cahuepé, AND C. M. Rebella. 2000. A calibration to estimate primary production of subhumid rangelands from remotely sensed data. Applied Vegetation Science 3:189-195.

Posse, G., and A. M. Cingolani. 2000. Environmental controls of NDVI and sheep production in the Tierra del Fuego steppe of Argentina. Applied Vegetation Science 3:253-260.

Posse, G., M. Oesterheld, and C. M. Di Bella. 2005. Landscape, soil and meteorological influences on canopy dynamics of northern flooding Pampa grasslands, Argentina. Applied Vegetation Science 8:49-56.

Rao, C. R. N., And J. Chen. 1995. Inter-satellite calibration linkages for the visible and near-infrared channels of the Advanced Very High Resolution Radiometer on the NOAA-7, -9 , and -11 spacecraft. International Journal of Remote Sensing 16:1931-1942.

Rasmussen, M. S. 1998. Developing simple, operational, consistent NDVIvegetation models by applying environmental and climatic information: part I. Assessment of net primary production. International Journal of Remote Sensing 19:97-117.

Reed, B. C., J. F. Brown, D. Vanderzee, T. R. Loveland, J. W. Merchant, and D. 0. OHLEN. 1994. Measuring phonological variability from satellite imagery. Journal of Vegetation Science 5:703-714.

ReEves, M. C., J. C. Winslow, and S. W. Running. 2001. Mapping weekly rangeland vegetation productivity using MODIS algorithms. Journal of Range Management 54:90-105.

Rouse, J. W., R. H. HaAs, J. A. Schell, D. W. Deering, and J. C. Harlan. 1974. Monitoring the vernal advancement of retro gradation of natural vegetation. Greenbelt, MD, USA: NASA/GSFC Type III Final Report. 371 p.

Running, S. W., P. E. Thornton, R. R. Nemani, And J. Glassy. 2000. Global terrestrial gross and net primary productivity from the Earth observing system. In: 0. E. Sala, R. B. Jackson, H. A. Mooney, and R. Howarth [EDs.]. Methods in ecosystem science. New York, NY, USA: Springer-Verlag. p. 44-57.

SalA, O. E. 2001. Productivity of temperate grasslands. In: H. A. Mooney, B. Saugier, and J. Roy [EDS.]. Terrestrial global productivity. New York, NY, USA: Academic Press. p. 285-300.

Singh, J. S., W. K. Lauenroth, and R. K. Steinhorst. 1975. Review and assessment of various techniques for estimating net aerial primary production in grasslands from harvest data. Botanical Review 41:181-232.

Soriano, A. 1991. Rio de la Plata grasslands. In: R. T. Coupland [ed.]. Natura grasslands: introduction and Western Hemisphere. Amsterdam, Netherlands: Elsevier. p. 367-407.

TAyloR, B. F., P. W. Dini, ANd J. W. Kidson. 1985. Determinations of seasonal and interannual variation in New Zealand pasture growth form noaa-7 data. Remote Sensing of Environment 18:177-192.

TucKER, C. J. 1980. A critical review of remote sensing and others methods for non-destructive estimation of standing crop biomass. Grass Forage Science 32:177-182.

Tucker, C. J., C. L. Vanpraet, M. J. Sharman, and G. Van Ittersun. 1985. Satellite remote sensing of total herbaceous production in the Senegalese Sahel 19801984. Remote Sensing of Environment 17:232-249.

Wanjura, D. F., And J. L. Hatfield. 1987. Sensitivity of spectral vegetative indices to crop biomass. Transactions of the ASAE 30:810-816. 